IBT Journal of Business Studies

Volume 15(1), 2019, 112-122

\title{
Trend of dividends disappearing and reappearing in Pakistani listed firms
}

\author{
Abdul Hameed ${ }^{18}$ \\ Muhammad Ayub Khan Maher ${ }^{2}$ \\ Akhtiar Ali \\ Mohammad Mohsin Khan ${ }^{4}$
}

\begin{abstract}
The objective of this study was to explore the main factors of dividend policy determinants. For this purpose, a sample of 150 listed firms in PSX taken into account for the period of 2008-2018. A secondary data taken from SBP publication, Stock exchange collected for this study and variables used size, debt ratio, profitability, size, investment, Firm's Maturity, Market Capitalization, Return on Equity (ROE), Growth in Sales and leverage was utilized using Panel regression techniques. Data of dividend shows most of the period dividend amount and dividend firms increased during the period of research 2008-18. The trend also shows that dividend pattern increase as base year data to end period study during both democratic governments. Study findings also show that three different aspects of the dividend payment propensity during 2008-2018. Results show that payment of dividend is declined mostly in the small and newly firms because they have less income generated from profit, younger firms, and firms as compared with highly investment pattern of firm, high debts, higher risk in their business and high tax rates on dividend. Study also finds a significant and positive association with propensity to pay dividend of catering theory and support the catering theory.
\end{abstract}

Keywords: Dividend, Catering theory, Size, Pakistan, Propensity to pay dividend

1. Lecturer, Ilma University \& PhD Scholar Iqra University Karachi, email: abdulhameedph.d@ gmail.com

2. Professor, Iqra University Karachi, Pakistan,

3. Senior Assistant Professor, BahriaUniversity Karachi, Pakistan

4. BahriaUniversity Karachi, Pakistan

Page $\mid 112$ 


\section{INTRODUCTION}

Distribution of profit to their shareholder of any firms with equal with respect to ownership of each shareholder defined as dividend by Frankfurt, Wood, and Wansley, (2003). Decision regarding pay or not pay dividend, as firms allocate corporate payout decision, with regard of financing from external, decision to retain profit of the current year for future investment or pay as dividend are critical decision for firm management. Almost sixty year, no particular consensus developed by different researcher, academic analysts as well as for firm stockholders.

Theory of irrelevance of dividend as put forward by Miller and Modigliani (1961) assume that if capital market is perfect where no taxes, zero cost of transaction, no agency conflict and all information shared equally with all stakeholders easily. There finding show that no change in share prices of firm if firm pay dividend to shareholders. From that day, two school of thought postulates their claims of perfect and imperfect market. They claim that world of perfect market, companies' value depends on investment policy of firm, both dividend and capital structure must care of investment decision of managers. While extensive field of research is carried forward regarding dividend, dividend policy remains a "puzzle" as stated in Black (1976), "The harder we look at the dividends picture, the more it seems like a puzzle, with pieces that just do not fit together" (p. 8).

Previously, most of studies focus on impact as well as determining factors of firm dividend policy on price of stock companies. Some studies (De Angelo et al., 2004; Fama \& French, 2001; Fatemi \& Bildik, 2012;Kuo, Philip, \& Zhang, 2013) have investigated the trend in policy of payout time to time, Fama and French (2001) document that the proportion of dividend payers among NYSE, AMEX, and NASDAQ specially from manufacturing as well as non-utility listed firm payout of dividend decreasing from apost-1972 peak of $66.5 \%$ in 1978 to $20.8 \%$ in 1999 . Findings of these studies explain that decline of dividend reasons are due to lower business size, less profit earn by firm, and lot of investment opportunity available. Other researcher suggest that this is called disappearing phenomenon and gave different reasoning. Fama and French (2004) statethat most of the newly listed proportion increases on the exchange which are very small and non-profitable firm whose share traded and named as publically quoted firms and characterized as non-paying firms. DeAngelo, DeAngelo, and Stulz (2006) study show that less mature have less to pay due to lower profit as well high investment opportunity as compare to mature firm which pays more dividend as a life-cycle explanation for declining dividend payers. Many researchers, like Grullon and Michaely (2002), and Skinner (2008) finds out that paying not profit as a dividend is substitute of share repurchase due to disappearing dividend in the market as an explanation. Their findings suggest that companies may distribute their funds to shareholder if not finance repurchase of shares.

Thus, it is important to examine the above-discussed phenomenon in this study relate to objective and questions. Is Pakistani firms threatened dividends disappear? If so, what risky factors more disturbing disappear of dividend from market? Has the propensity to pay dividends reduced in the Pakistani context?

This study uses the data to explore the appearance and disappearance of the dividend for the sample of 150 listed companies of Pakistani stock exchange, where from last decades made comprehensive policies regarding taxes, setting of different institutions of the financial market as well as economic perspective changes with comprehensive and significant role for development to build confidence of investors, for the period 2008-2018. 
IBT Journal of Business Studies Volume 15(1), 2019

The pattern of remaining parts follow as literature review part 2, research method discussed in part 3 , results and finding part 4 and finally conclusion at the end.

\section{REVIEW OF LITERATURE}

Fatemi and Bildik (2012) state that there is a significant relationship of payout propensity of dividend using 17000 firms of different countries listed exchanges pattern. Also relate with Fama and French study results and no changes with other studies on catering theory.

Kuo, Philip and Zhong (2013) test the disappearing of firm dividend policy using as a different countries sample for the period of 1989 to 2011. Results show that impact of risk is more explanatory variables with propensity to pay dividend and liquidity is also important factors. There finding also suggest that risk is also higher for dividend paying firm operation in the United States, France, United Kingdom, and other European markets.

\section{Dividend Policy Determinants}

\section{Firm-specific characteristic variables}

Internal factors that affect corporation payout policy of dividend show a significant relationship with specific factors for instance investment of firms, size as well as earning of firms Fama and French (2001). Using logit model with a variable payment of dividend decision equal to 1 and otherwise 0 in any specific period by firm. Finding also show that high profit and mature firms distribute more dividend as compare with less growth opportunities as well as less investment pay lower dividend to their shareholders.

In this study, we include firm specific variables such as size, investment purpose and Profit of firm as determining factors of payout policy decision for test.

\section{Financial leverage variable}

Previous studies shows that firms leverage mostly hurdle for payment of dividend and lower the payment of dividend of firms due to payment of contract amounts Smith and Warner (1979) and Kalay (1982). Rozeff (1982) explain that higher the debt to equity ratio leads to lower distribution of dividend of firm to shareholders which might lower the higher cost of transaction related to external financing. This variable resolve the agency conflict rises between managers and owners of firms (Jensen, 1986; Jensen \& Meckling, 1976; Rozeff, 1982) along with asymmetries of information among investors and firms (Ross, 1977).

\section{Firm life-cycle}

Most of the time companies follow an accounting principles of business continue for future relate with theory of life cycle. This confirms that as firm more mature pay higher dividend as compare with younger firms. Because smaller and young firm needs high amount for investment with less profit to meet its need for financing and may face for raise their funds from external financing. For this purpose, they reserve cash for investment not for pay to dividend.

On contrary, more mature firm with higher cash, higher profit and fewer amounts required for their investment and growth purpose. They distribute their earning as dividend to shareholders (Bulan,Subramanian, \& Tanlu, 2007; DeAngelo et al., 2006; Denis \& Osobov, 2008; Grullon, Michaely, \& Swaminathan, 2002).

Page | 114 


\section{Risk factor}

Previous studies finds negative relationship between payment of dividend with market and firm risk. Some studies like Venkatesh (1989) and Dyl and Weigand (1998) shows that lower the un systematic risk with initiation of dividend. Boehme and Sorescu (2002), and Grullon et al. (2002) examine that as dividend increases by firm lower the systematic risk of the firm.

\section{Tax variable}

If firm increase their stock value then lower the payout ratio of dividend the firms. This assume that investor prefer lower taxes should prefer shares with higher dividend and vice versa Litzenberger \& Ramaswamy, (1979).

\section{HYPOTHESES}

H1a: There is positive significant relationship between size and firms dividend decision policy. H1b: There is positive significant relationship between profitability and firm's dividend decision policy.

H1c: There is negative significant relationship between Investment opportunity and firm's dividend decision policy.

$\mathrm{H} 2$ : There is negative significant relationship between leverage and firms dividend decision policy. H3: There is positive significant relationship between life cycle variable and firms dividend decision policy.

H4: There is negative significant relationship between Firm as well as market risk and firms dividend decision policy.

H5: There is negative significant relationship between tax and firms dividend decision policy.

\section{RESEARCH METHOD}

In this study Subsequent of Fama and French (2001) in addition quite a lot of other succeeding researchers like Denis and Osobov (2008), Hoberg and Prabhala (2009), Reddy and Rath (2005), Fatemi and Bildik (2012), Kuo et al. (2013), and Labhane (2017). To check the effect of different factors like market as well firm related variables with macroeconomics factor on paying decision of dividend probability of any firm during specific period was utilized through logit regression model. The model for this study is:

DPNTPit $=\alpha 0+\alpha 1$ Sizeit $+\alpha 2$ Profitit $+\alpha 3$ investit $+\alpha 4$ growthit $+\alpha 5$ levit $+\alpha 6$ LCit $+\alpha 7$ Firm Riskit $+\alpha 8$ MKT Riskit $+\alpha 9$ Taxesit + git-

The above equation shows that DPNTP $=1$ when company make decision about dividend payment in any period $\mathrm{t}$, and otherwise 0 , Size $=$ Size $=\log$ of market capitalization, Profitability $=$ Profit $=$ PROFIT is profit after taxes, INVTEST $=$ market value divided by book value is used for investment proxy Growth $=$ GRW is change in sale from different of current and previous year sale Leverage $=$ LEVis a ratio of total liabilities divided by shareholder equity Life Cycle $=$ Retained earning divided by shareholder equity as a life cycle proxy Firm Risk $=$ firm factor Standard deviation of residuals values of CAPM from regression Market Risk $=$ Beta of market as the standard deviation of the predicted valuefrom a CAPM Taxes $=$ amount or $\%$ of Tax charge on individual dividend 
IBT Journal of Business Studies Volume 15(1), 2019

$\alpha$ is a constant, $\alpha 1-\alpha 7$ are slope coefficients and citrepresent error term.

Results of model shows the log of odds ratio and derivative of independent with respect to $\mathrm{x}$, which show the probability of change in one independent variable as other variable kept constant. We use Pseudo R square value for binary logistic results rather R square due to less meaningful for model of good fit. We also apply likelihood ratio test to test the null hypotheses using $\mathrm{F}$ test value for all coefficients equal to zero with slope.

\section{Data Collection}

These above mentioned data are obtained from various SBP financial statement 5 years, Economic survey and Pakistan stock exchange for share price data, annual reports data, and so on, for good analysis with best interpretation of the output.

Currently, 559 companies are enlisted on PSX, 153 companies are from financial and 406 companies are non-financial and comprise with 35 sectors. To select an appropriate sample we utilized the methodology of many renowned researches conducted in the different countries with developed and developing economies. These famous studies are Fama and French (2001), and Labhane (2017). Only manufacturing sectors data will be taken for study hypothesis test.

Characteristics of dividend payers and non payers

Figure 1: Number of listed companies in Pakistani Stock

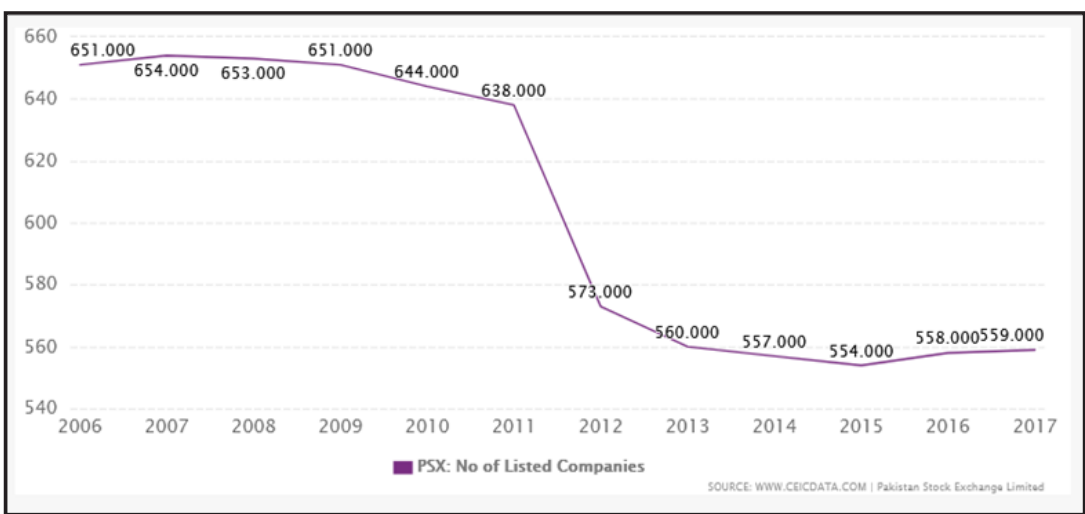

This table shows that trend of listed firm decrease from 2006 to 2017 after the dictatorship government change and now from 2012 to 2017 shows a constant number of listed firms from 550570. On the other hand, dividend paying firms increases when number of listed firm's decreases due to some strict listing criteria introduced by SECP and stock exchange.

Table 1: Trends in dividend payers and non payers

Cash and Stock Dividend paid in each year

\begin{tabular}{|l|l|l|l|l|l|}
\hline Year & $\begin{array}{l}\text { Total listed } \\
\text { firms }\end{array}$ & $\begin{array}{l}\text { Dividend } \\
\text { Paying firm }\end{array}$ & $\begin{array}{l}\text { Dividend not } \\
\text { Paying firm }\end{array}$ & $\begin{array}{l}\text { Stock } \\
\text { Dividend }\end{array}$ & Total dividend \\
\hline 2017 & 559 & 248 & 311 & 26 & 1206064 \\
\hline 2016 & 558 & 244 & 314 & 23 & 904906.2 \\
\hline 2015 & 554 & 238 & 316 & 17 & 795266.3 \\
\hline 2014 & 557 & 223 & 334 & 23 & 534359.1 \\
\hline
\end{tabular}


IBT Journal of Business Studies Volume 15(1), 2019

\begin{tabular}{|c|c|c|c|c|c|}
\hline 2013 & 560 & 230 & 330 & 67 & 141032.564 \\
\hline 2012 & 573 & 230 & 343 & 46 & 321012.4 \\
\hline 2011 & 638 & 235 & 403 & 49 & 372054.6 \\
\hline 2010 & 644 & 233 & 411 & 62 & 205384.5 \\
\hline 2009 & 651 & 166 & 485 & 64 & 127941 \\
\hline 2008 & 653 & 191 & 462 & 85 & 189234 \\
\hline 2007 & 654 & 220 & 434 & 105 & 150712.5 \\
\hline 2006 & 651 & 243 & 408 & 111 & 108768.4 \\
\hline 2005 & 645 & 258 & 387 & 118 & 118586.1 \\
\hline 2004 & 632 & 248 & 384 & 93 & 5175668.204 \\
\hline 2003 & 612 & 293 & 319 & 85 & 48873.18 \\
\hline 2002 & 613 & 293 & 320 & 48 & 42986.01 \\
\hline 2001 & 612 & 299 & 313 & 33 & 29347.89 \\
\hline
\end{tabular}

This table represent the companies paying phenomenon with increases during Musharraf's era but decreasing during democratic government two period. During the Musharraf's era both stock dividend and cash dividend paying increase but total cash dividend not too much but during Nawaz Sharif, s government this total payment of cash dividend trend increased. We categorized dividend paying firm into three groups, group 1, indicate increase in cash dividend paying firms for the period 2001-2007, group 2, show that declined in paying cash dividend due to change in governments, terrorist attack, and assignation of Benazir Bhutto during 2008-2013, and group 3, show an increase as well both total cash dividend and paying firm increased.

Above discussion shows that companies which pays dividend in Pakistani listed firms pattern of paying firms increase and not constant by other studies results finding Famaand French (2001) for United States stock market. They finds that number of dividend paying firms decreasing from $66.5 \%$ in 1978 to $20.8 \%$ in 1999 , conversely results of French companies inconsistent with Fama and French study.

Figure 2:

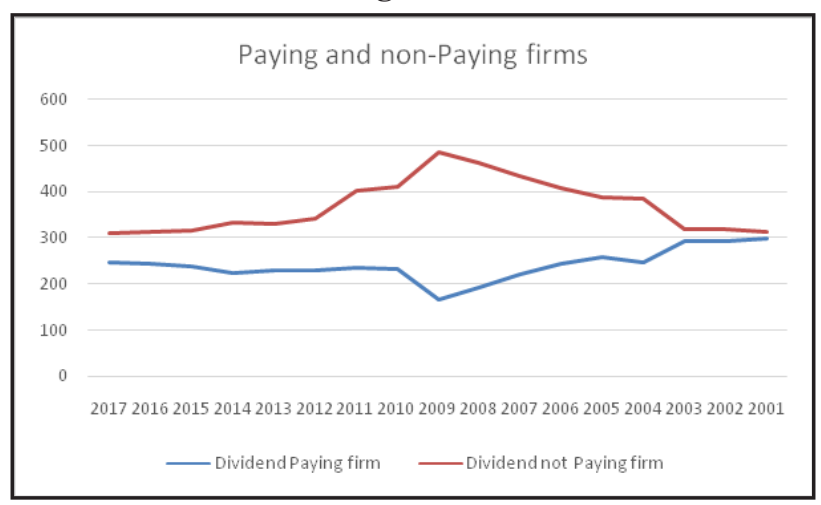

Figure 2 shows the trend listed firms over the period of 2001-2017 dividend payers and non payers over the period of study. We find out three different groups of dividend payment trend payers as well 
IBT Journal of Business Studies Volume 15(1), 2019

as non-payers. The trend shows positive during two periods but decline in dividend paying firms during PPP Government.

\section{Concentration of total dividends paid}

Dividend is s distribution of profit to a shareholder at each period. So investor concentrates highly on dividend paying firms. This is reliable with the preceding

results of DeAngelo et al.(2004), Eije and Megginson (2008) and Labhane (2017).

\section{Concentration of earnings of dividend-paying firms}

Many renowned researchers like Lintner (1956), Fama and Babiak (1968), and DeAngeloet al. (2004) propose that factors that affect dividend payout policy decisions is key of a profitability.

\section{Empirical results \\ Result of logit regressions}

Table 2 shows the output of logit model that is estimated based on equation (1) for period 20082018. The variable propensity to pay dividend is dependent variable which have value o and 1 .

Table 2: Logit Regression Results.

Dividend Payout Ratio as Dependent Variable

\begin{tabular}{|l|l|l|}
\hline & $2008-2018$ & \\
\hline Variable & Coefficient Estimates & Marginal Effects \\
\hline Constant & $-4.96^{* *}(-14.08)$ & \\
\hline Size & $1.28^{\star *}(17.77)$ & 0.146 \\
\hline Profit & $3.832^{\star *}(10.46)$ & 0.752 \\
\hline Invest & $-0.21^{\star *}(-5.02)$ & -0.039 \\
\hline Growth & $0.642^{\star *}(4.85)$ & 0.103 \\
\hline Leverage & $-0.317^{* *}(-3.95)$ & -0.211 \\
\hline LC & $1.34^{\star *}(3.01)$ & 0.211 \\
\hline Firmrisk & $-0.312^{\star}(-2.35)$ & -0.012 \\
\hline Mktrisk & $-0.250(-1.23)$ & -0.226 \\
\hline Taxes & $-0.267^{\star *}(-7.69)$ & -0.105 \\
\hline No of Observations & 1650 & \\
\hline Log Likelihood & -2577.409 & \\
\hline Wald Test & $\chi^{2}(9)=860.43(0.000)$ & \\
\hline LR Test & $\chi^{2}(01)=1511.58(0.0000)$ & \\
\hline
\end{tabular}

The Figures in parentheses are the t-statistics. * indicates significance at 5\% level, ** indicates significance at $1 \%$ level.

Table 2 shows that results are similar as expected and relate with Fama and French (2001) characteristics as well as higher significant values at $1 \%$ level. All the hypotheses accepted with a significant relation. Firm size, profitability, growth and life cycle proxy has positive relation with 
significant and remaining variables negative relation with significant values. Significant mean these positive and negative values must affect the dividend of paying firms decision. This also show that if any increase in independent variables may increase dependent and vice versa.

\section{Catering theory and the propensity to pay dividends}

\section{Trends in dividend payers and non payers}

Trend in Pakistani payers and non payers shows a better trend as compared with other developed nation economies. We assume to test the propensity to pay dividend (PTPt) in period of study increases or decreases.

Following Fama and French (2001), taken as a base for calculation of our dependent variable expected payment of dividend percentage through logit model that includes the size, profitability, growth opportunities, and investment opportunities as the independent variables during the base period 2008-18. The logit model is specified as follows:-

$$
\operatorname{pr}\left(\text { Payer }_{\mathrm{i}}=1\right)=\operatorname{logit}\left\{\omega_{0}+\omega_{1} \mathrm{SIZE}_{\mathrm{i}}+\omega_{2} \mathrm{PROF}_{\mathrm{i}}+\omega_{3} \mathrm{GRW}_{\mathrm{i}}+\omega_{4} \mathrm{INVT}_{\mathrm{i}}+\grave{\mathrm{o}}_{\mathrm{i}}\right\}
$$

Catering incentives and the propensity to pay dividends

To find out the relationship between propensity to pay dividend and catering incentives by using regression for our dependent variable (PTPt) against (DPt-1) variable. The regression model takes the following form:-

$\Delta \mathbf{P T P t}=\boldsymbol{\theta}+\pi \mathrm{DPt}+\varphi \mathrm{t}$

Where $\triangle \mathrm{PTPt}$ measure the propensity to change in payment of dividend, DPt-1 measures the effect of previous payment of dividend behavior use as a catering incentives, $\theta$ is aconstant, $\pi$ is a slope coefficient and $\varphi t$ is the error term in year $t$.

Table 3: Result of the Regression analysis.

\begin{tabular}{|c|c|}
\hline Variable & Model \\
\hline Constant & -0.003 \\
\hline & $(-0.101$ \\
\hline DPt-1 & $0.358^{* *}$ \\
\hline & $(5.78)$ \\
\hline Adjusted R2 & 0.645 \\
\hline Durbin-Watson & 1.979 \\
\hline
\end{tabular}

All slopes of coefficients of DPt-1 mean lagged premium dividend has direct as well as significant association for study model, thus results of above table reminds that change in probability of payment with positive relationship for premium dividend.

So, positive dividend premium keeps investor to invest his premium amount on that company which pay dividends. This suggest that managers use dividend premium as a cater the investor and provide a good image in the mind of investor through dividend payment behavior. If negative relation with payout decision among premium dividend show a negative for cash collection from outsider. Our finding more consistent with researcher such as Baker and Wurgler (2004a, 2004b) and supports the catering incentives of dividend payment. 
IBT Journal of Business Studies Volume 15(1), 2019

\section{CONCLUSION}

The objective study is to examine the factors that affect dividend using a sample 150 firm listed in PSX during 2008-2018. In this study, we empirically test to what extent the company internal variables, market factors as well economic variables be able to enlighten a firm's probability of paying dividends. Using trend analysis, we find three types of changing dividend behavior of firm for both payers and non payers, where the payers of dividend disappeared during 2008-2011, reappeared during 2001-07 and again reappeared during 20012-18. Although the number of dividend-paying firms declined the aggregate dividends as well as aggregate earnings increased consistently of dividend paying firms but decreasing trend in non-paying firms during 2008-2018. Our findings also represent an increasing number of payers in Pakistan with huge amount of dividend and in last decade's trend of paying companies also changes with good numbers. Thus, we check and accomplish that earnings as well as dividends relate highly each other's with less payers.

On the other hand, comparing payers and non-payers dividend firms show a distinct among higher size, profit, less investment opportunity and more mature rather than non-payers. However, less relevant with higher growth ways than non-payers of dividend and most of the research finds mixed evidence with leverage of firms.

Study results represent that firm size, profitability, leverage, maturity of firm, investment, risk of both market as well as firm and dividend taxation are the key factors to explain dividend policy of any Pakistani listed firms. Our study findings show that business risk, market risk, market to book value ratio, leverage, debt ratio, and tax on dividend amount affect the propensity to pay dividend with negative association, but firms size, life cycle proxy as well as profitability show a positive effect on dividend propensity to pay dividend.

Additionally, finding show that there is a significant positive relationship of catering theory for the probability of propensity to pay dividend paying firms. So, out finding support the managers cater rational behavior support, using dividend as a catering to investor may demand for dividend when investor place his investment on the payers firm and versa.

Policy Implication of this study contribute to the emerging finance literature that examines the role of investor attention in corporate decisions. Managers, owners, shareholder must changes in dividend and they invest more on dividend paying firms. In future work, it may be interesting to study related to other corporate decisions such investment decision, size, corporate governance and taxes.

\section{REFERENCES}

Acharya, V. V., Gujral, I., Kulkarni, N., \& Shin, H. S. (2011), "Dividends and bank capital in the financial crisis of 2007-2009” (Working paper w16896). Cambridge, MA: National Bureau of Economic Research.

Agarwal, R. N. (2000). "Capital market development, corporate financing pattern, and economic growth in India (Working paper 01/2000).” New Delhi, India: Institute of Economic Growth.

Amihud, Y., \& Li, K. (2006). "The declining information content of dividend announcement sand the effects of institutional holdings." Journal of Financial and Quantitative Analysis, 41,637-660.

Baker, H. K. (2009). "Dividends and dividend policy." Hoboken, NJ: John Wiley \& Sons.

Baker, M., \& Wurgler, J. (2004a). "A catering theory of dividends.” Journal of Finance, 59,11251165. 
Baker, M., \& Wurgler, J. (2004b). “Appearing and disappearing dividends: The link to catering incentives." Journal of Financial Economics, 73, 271-288.

Banerjee, S., Gatchev, V. A., \& Spindt, P. A. (2007). "Stock market liquidity and firm dividendpolicy.”Journal of Financial and Quantitative Analysis, 42, 369-397.

Bank, S., Cheffins, B., \& Goergen, M. (2009). “Dividends and politics.”European Journal ofPolitical Economy, 25, 208-224.

Boehme, R. D., \& Sorescu, S. M. (2002). “The long-run performance following dividendinitiations and resumptions: Underreaction or product of chance?” Journal of Finance, 57,871-900.

Bulan, L., Subramanian, N., \& Tanlu, L. (2007). “On the timing of dividend initiations.” Financial Management, 36, 31-65.

DeAngelo, H., DeAngelo, L., \& Skinner, D. J. (2004). “Are dividends disappearing? Dividend concentration and the consolidation of earnings." Journal of Financial Economics, 72, 425-456.

DeAngelo, H., DeAngelo, L., \& Stulz, R. M. (2006). "Dividend policy and the earned/ contributedcapital mix: A test of the life-cycle theory." Journal of Financial Economics, 81, 227-254.

Denis, D. J., \& Osobov, I. (2008). "Why do firms pay dividends? International evidence on the determinants of dividend policy." Journal of Financial Economics, 89, 62-82.

Eije, H., \& Megginson, W. L. (2008). "Dividends and share repurchases in the European Union."Journal of Financial Economics, 89, 347-374.

Fama, E. F., \& French, K. R. (2001). "Disappearing dividends: Changing firm characteristics orlower propensity to pay?" Journal of Financial Economics, 60(1), 3-43.

Fama, E. F., \& French, K. R. (2004). "New lists: Fundamentals and survival rates." Journal of Financial Economics, 73, 229-269.

Fatemi, A., \& Bildik, R. (2012). "Yes, dividends are disappearing: Worldwide evidence." Journalof Banking \& Finance, 36, 662-677.

Ferris, S. P., Sen, N., \&Yui, H. P. (2006a). “Are fewer firms paying more dividends? Theinternational evidence.” Journal of Multinational Financial Management, 16, 333-362.

Frankfurter, G., Wood, B. G., \&Wansley, J. (2003). "Dividend policy: Theory and practice." SanDiego, CA: Academic Press.

Grullon, G., Michaely, R., \&Swaminathan, B. (2002). "Are dividend changes a sign of firmmaturity?"Journal of Business, 75(3), 387-424.

Hoberg, G., \& Prabhala, N. R. (2009). "Disappearing dividends, catering, and risk." Review of Financial Studies, 22, 79-116.

Jensen, M. C. (1986). "Agency cost of free cash flow, corporate finance, and takeovers."American Economic Review, 76, 323-329.

Julio, B., \& Ikenberry, D. L. (2004). "Reappearing dividends." Journal of Applied Corporate Finance, 16, 89-100.

Kuo, J. M., Philip, D., \& Zhang, Q. (2013). "What drives the disappearing dividends phenomenon?"Journal of Banking \& Finance, 37, 3499-3514.

Lintner, J. (1956). "Distribution of incomes of corporations among dividends, retained earnings, and taxes."American Economic Review, 46, 97-113.

Litzenberger, R. H., \& Ramaswamy, K. (1979). "The effect of personal taxes and dividends oncapital asset prices: Theory and empirical evidence.” Journal of Financial Economics, 7, 163-195.

Miller, M. H., \& Modigliani, F. (1961). "Dividend policy, growth, and the valuation of shares." Journal of Business, 34, issue-4411-433.

Nishant B. L (2017). "Disappearing and Reappearing Dividends in Emerging Markets: Evidence from Indian Companies, “ Journal of Asia-Pacific Business,

Reddy, Y. S., \& Rath, S. (2005). "Disappearing dividends in emerging markets? Evidence 
IBT Journal of Business Studies Volume 15(1), 2019

fromIndia.’Emerging Markets Finance and Trade, 41, 58-82.

Skinner, D. J. (2008). "The evolving relation between earnings, dividends, and stock repurchases." Journal of Financial Economics, 87, 582-609. 